\title{
Morphology of the capsule-like portion of the reactive membranes on intraocular lens implants
}

\author{
J. Reimer Wolter \\ The Department of Ophthalmology and Pathology of the University of Michigan Hospitals, Ann Arbor, Michigan, USA
}

\begin{abstract}
Ábstract. The glass-membrane-like capsules probably are the practically most important part of the separating membranes that typically form on intraocular lens implants in the human eye. With time in the eye, these clear capsules become tougher, more firmly adherent, and less eosinophilic. Their formation occurs early after implantation and is associated with the reactions of intraocular macrophages. Examples of well developed capsules are presented to show that only few cells are needed for their maintenance and that they can be of irregular thickness. Cell life on the filmlike capsules is demonstrated using the examples of bloodeating macrophages, epitheliod cells, and melanocytes. Attachment of fibrous structures containing zonular fibers to the haptics is recorded.
\end{abstract}

Zusammenfassung. Die glasmembran-ähnlichen Kapseln sind wahrscheinlich der wichtigste Teil der trennenden Membranen, die sich typischerweise auf intraokulaeren Linsenprothesen bilden. Im Auge werden diese klaren Kapseln mit der Zeit zäher, fester anhaftend und weniger eosinophil. Thre Bildung geschieht im Auge bald nach der Implantation und ist mit den Reaktionen der intraokulären Makrophagen verbunden. Beispiele von voll entwickelten Kapseln werden gezeigt, um zu zeigen, daß nur wenige Zellen zu ihrer Instandhaltung notwendig sind und daß sie von sehr unregelmäßiger Dicke sein können. Das Zelleben auf den filmartigen Kapseln wird am Beispiel von blutfressenden Makrophagen, Epithelioidzellen und Melanozyten demonstriert. Das Anhaften von fibrösen Strukturen, die Fasern der Zonula lentis enthalten, an haptische Teile der Linsenprothesen wird beschrieben.

Study of more than fourty intraocular lens implants removed from human eyes within the last two years for different reasons and under different conditions has revealed evidence of a film-like proteinaceous capsule as part of cellular membranes on the plastic surface of all implants [1-8]. These capsules typically are continuous and of regular thickness in clinically successful cases. They are slightly

\footnotetext{
* Supported by The Research To Prevent Blindness, Inc., New York

Offprint requests to: J. Reimer Wolter, M.D., Department of Ophthalmology, University of Michigan Hospitals, Ann Arbor, Michigan 48109 , USA
}

eosinophilic and they usually are populated by a variety of cells, most of which originate from free moving macrophages (phagocytes, histiocytes) of the inner eye [6,9]. Just like the cells of these membranes, the capsules are usually optically clear before histological staining. On the stained implants the capsules are best recognized, when they are detached or wrinkled. In some instances the capsules with attached cells have been studied in isolation, after they had come off the implant [4]. The capsules tend to come loose, when the implants are removed from the eye. They also tend to shrink and come loose during the dehydration process after the cytological staining - just before they are placed in embedding fluid under a cover glass [1]. This latter technical problem may have to do with the fact that the Xylol solution used for clearing of the stained and dehydrated specimen just before embedding often tends to start dissolving the plastic surface. The short exposure to Xylol is necessary, however, because the alcohol used for dehydration causes slight superficial clouding of the plastic and this disappears during the final exposure to Xylol.

It is my experience that the film-like capsules on lens implants become tougher and increasingly more adherent to the plastic surface with time. A continuous capsule was already present on an implant removed three months after its placement in an eye [6]. However, after only three months this capsule was extremely friable and it stained much more eosinophilic in comparison to capsules on implants removed after longer periods in the human eye. To concentrate on the morphological description of the capsular portion of interesting membranes on three implants on the background of impressions gained by the study of all earlier cases is the purpose of the present paper.

First case: This 88 year-old female patient had an intracapsular cataract extraction in her right eye in 1978. An intraocular lens implant of the so-called Sputnik type was placed. The immediate postoperative result is said to have been good, but no details are known. Corneal edema gradually developed about one year after the lens implantation. Slowly, this changed into very bothersome and irritating bullous keratopathy. A penetrating corneal transplant was done by Roger F. Meyer, M.D. of this Ophthalmology Department on 12.20.82. The Sputnik implant was removed and immediately fixed in buffered $10 \%$ Formalin.

Histological study of the corneal button showed advanced atrophy of the endothelium associated with edema as well as diffuse infiltration with PMN's in the stroma 


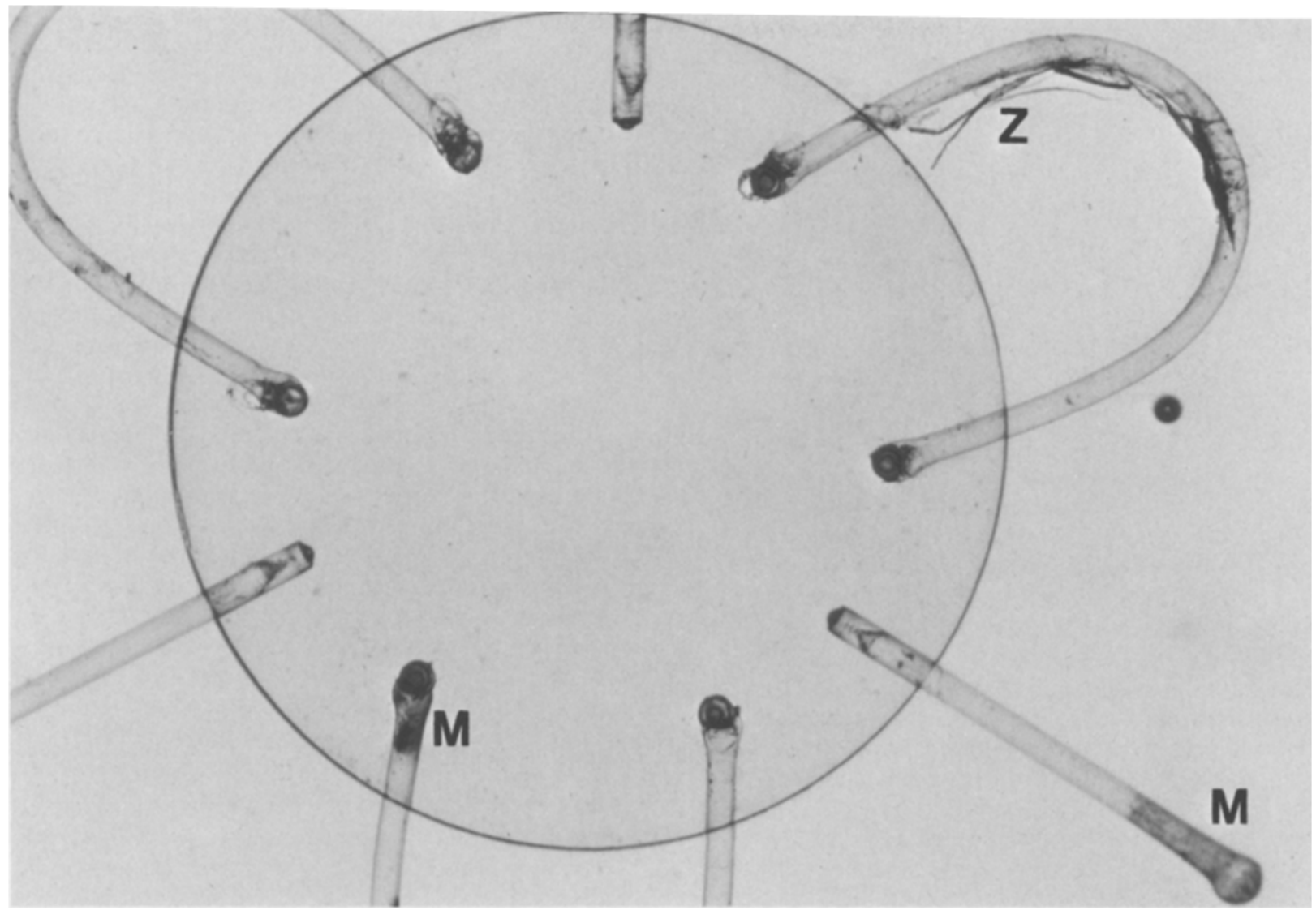

Fig. 1. First case, low power of Sputnik lens removed 4 years after implantation exhibits a firm and continuous glass-membrane-like capsule. Multinucleated giant cells $(M)$ are seen near the end of one anterior stave and at the insertions of the posterior loops. Fragments of zonular fibers $(Z)$ are attached to one posterior loop with fibrous strands. - Lens implant cytology technique, H and $E$ stain, photomicrograph $\times 20$

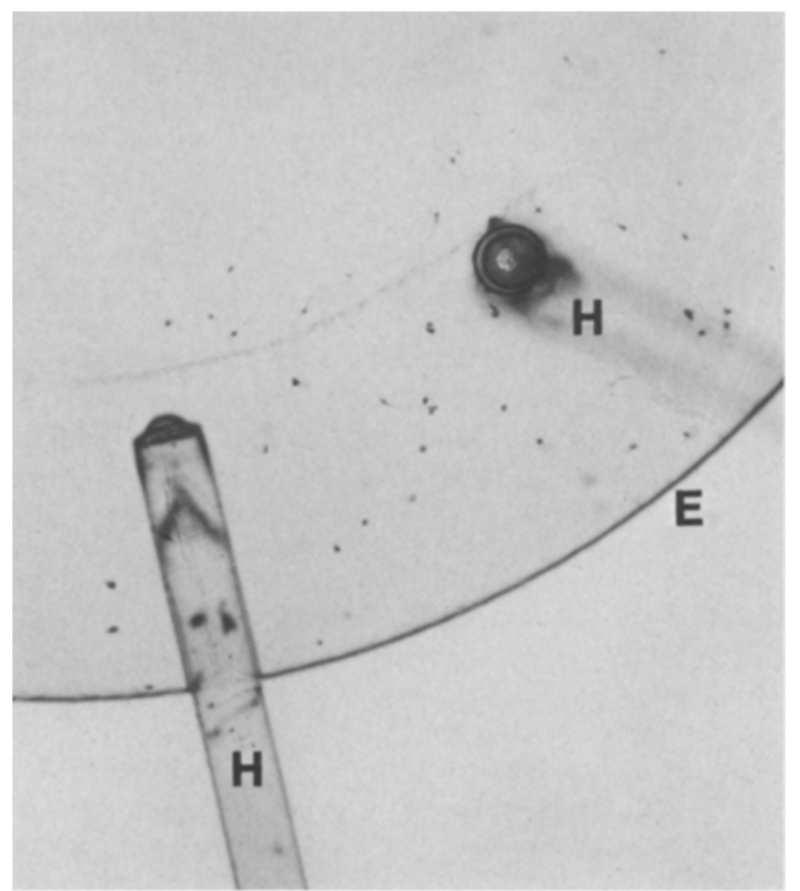

Fig. 2. First case, higher power shows dot-like macrophages and fibroblast-like cells on the surface of the clear capsule all over the optic portion of the implant. The capsule goes continuously around the edge $(E)$ of the lens. Two haptics $(H)$ are seen. - Lens implant cytology technique, $\mathrm{H}$ and $\mathrm{E}$ stain, photomicrograph $\times 52$ and loss of most of the epithelium. Lens implant cytology. study [1], revealed a thin and slightly eosinophilic film-like capsule evenly covering all parts of the implant. This was firmly adherent and did not detach or wrinkle during the surgical removal or the staining and embedding process (Fig. 1). The capsule was populated by only relatively few active macrophages (fibroblast-like cells) (Figs. 2 and 3). These had round or oval nuclei and most of them had an elongated cell body with irregular pseudopodia (Fig. 3). Different amounts of granular pigment were seen in the protoplasm of these cells. No giant cells were found on the optic portion of the implant, but large multinucleated cells of this type were seen near the clubshaped end of one of the straight haptics and at the insertion of haptics in the body of the implant (Fig. 1). One of the loop-like haptics had loose fibrous tissue containing remnants of zonular fibers anchored to it (Fig. 1).

Second case: Both eyes of this 90 year-old female were obtained at autopsy a day after she died on 10.15.82. The eyes were fixed in buffered $10 \%$ Formalin at that time. Twelve years before her death the patient had been operated by a local surgeon for her left cataract with an uncomplicated intracapsular cataract extraction. Normal vision was achieved in that eye with a contact lens. Nine years before her death an intracapsular cataract extraction was done in her right eye by the same surgeon and a medallion type of intraocular lens implant supported by one iris suture was placed. Central vision in the right eye once improved 


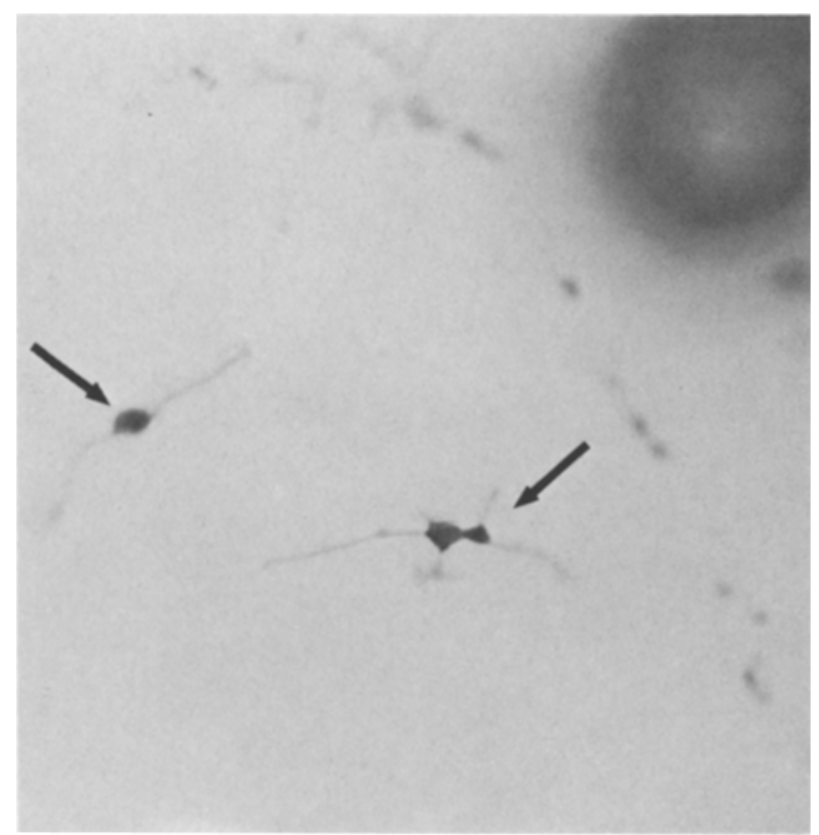

Fig. 3. First case, high power shows two typical macrophages with branching pseudopodia (arrows) on the surface of the clear and continuous capsule. The insertion of a haptic on the upper right.

Lens implant cytology technique, $\mathrm{H}$ and $\mathrm{E}$ stain, photomicrom graph $\times 150$ to $20 / 30$ during the first few months after surgery, but it kept changing and stabilized around 20/50. A fluorescein angiogram was obtained, but this is said not to have supported the diagnosis of cystoid macular edema. About two years after surgery the right eye developed sudden additional vision loss to $20 / 400$ due to a retinal branch vein occlusion. Secondary glaucoma with rubeosis iridis and ectropion uveae developed in this right eye. When the patient was last seen by the surgeon on 7-15-80, the right eye had gone blind and had an intraocular pressure of $60 \mathrm{~mm} \mathrm{Hg}$, but it was not painful. The iris suture supporting the implant had ruptured spontaneously and the implant had moved forward slightly, but it was not touching the cornea.

The right eye was of normal size. When the eye was opened, the anterior chamber was found to be shallow, the lens implant was in proper position in the pupil and offered no resistance to its removal, the vitreous was retracted and contained much blood. More blood was seen on the surface of the optic nerve head. Paraffin sections of this right eye revealed in the cornea a partial fibrous pannus and some diffuse atrophy of the endothelium. In one zone the endothelium was replaced by proliferating melanocytes from the iris. The chamber angle was closed by anterior peripheral synechiae. The iris exhibited rubeosis and ectropion uveae. The iris stroma showed much irregular atrophy of its stroma and pigment epithelium. The vitreous face was intact and partly degenerated blood was accumu-

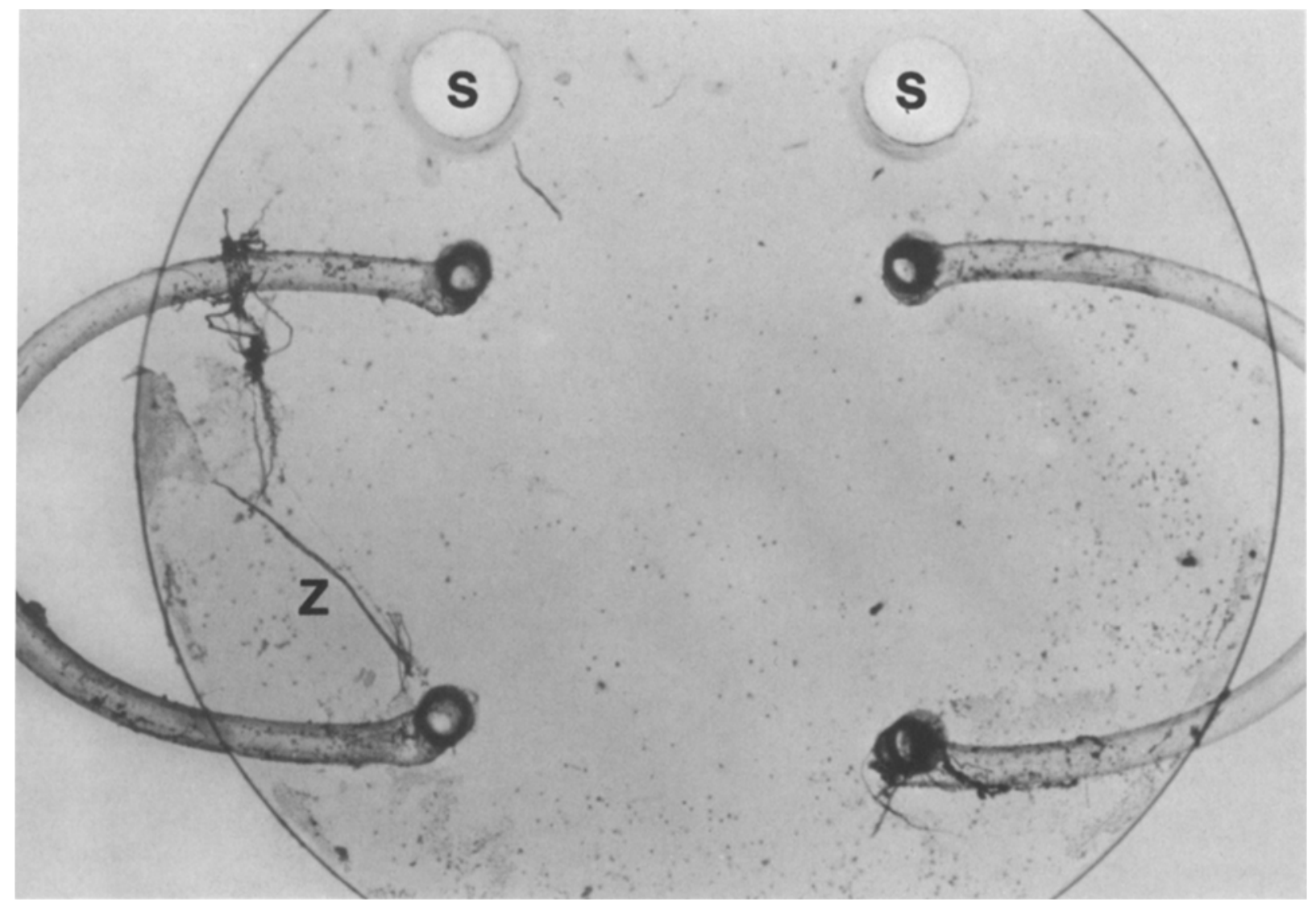

Fig. 4. Second case, Medallion lens removed 9 years after implantation with suture holes $(S)$. The implant is covered all over with a continuous capsule exhibiting small cells and blood remnants seen as small dots. Loose fibrous tissue with fragments of zonular fibers $(Z)$ seen on one haptic: - Lens implant cytology technique, H and E stain, photomicrograph $\times 20$ 


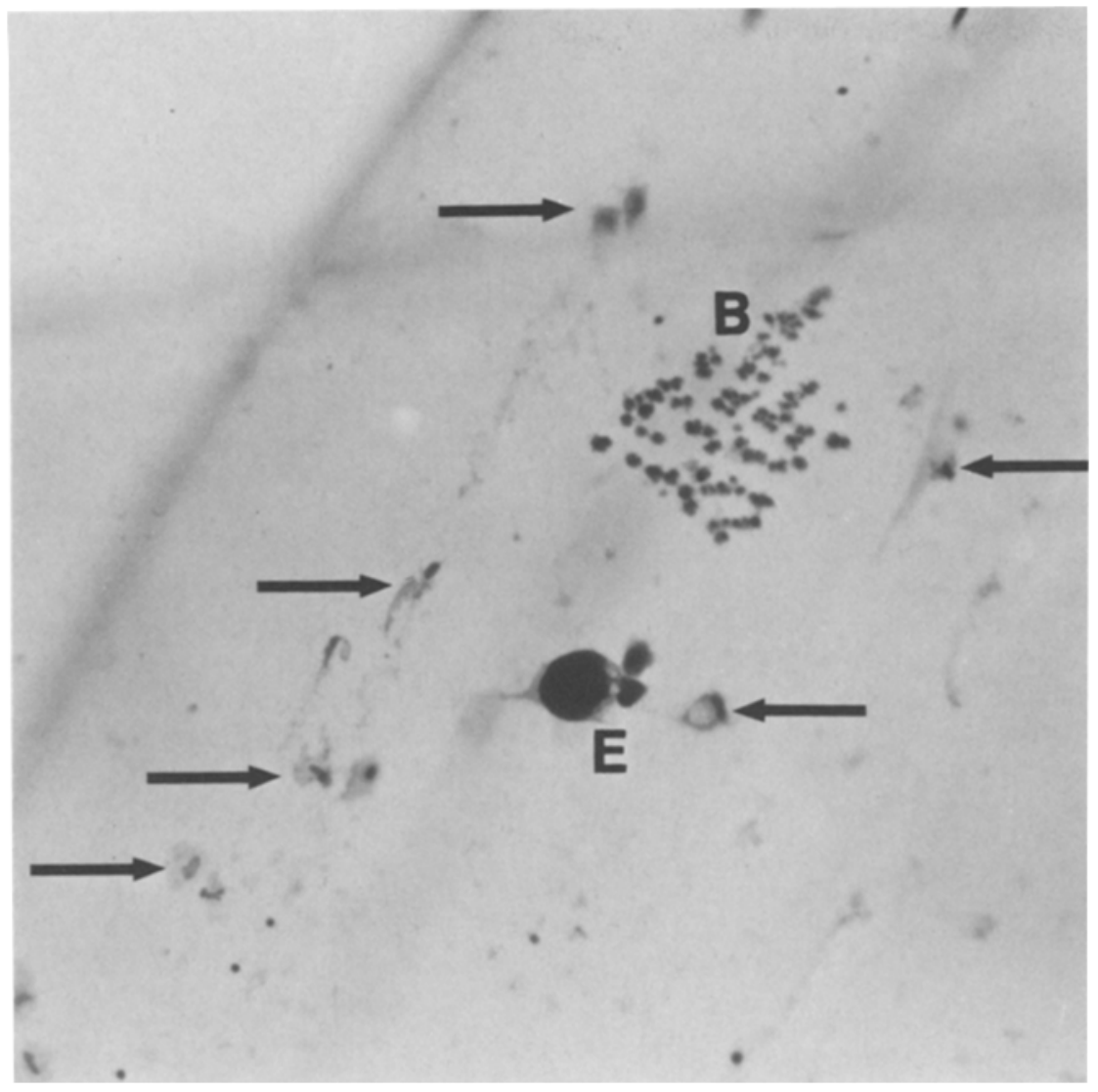

Fig. 5. Second case, higher power shows macrophages (arrows), one epithelioid cell with a giant nucleus $(E)$, and degenerated basophilic blood corpuscles $(B)$ on the capsule of the implant. The edge of the implant is on the upper left. - Lens implant cytology technique, $\mathrm{H}$ and $\mathrm{E}$ stain, photomicrograph $\times 125$

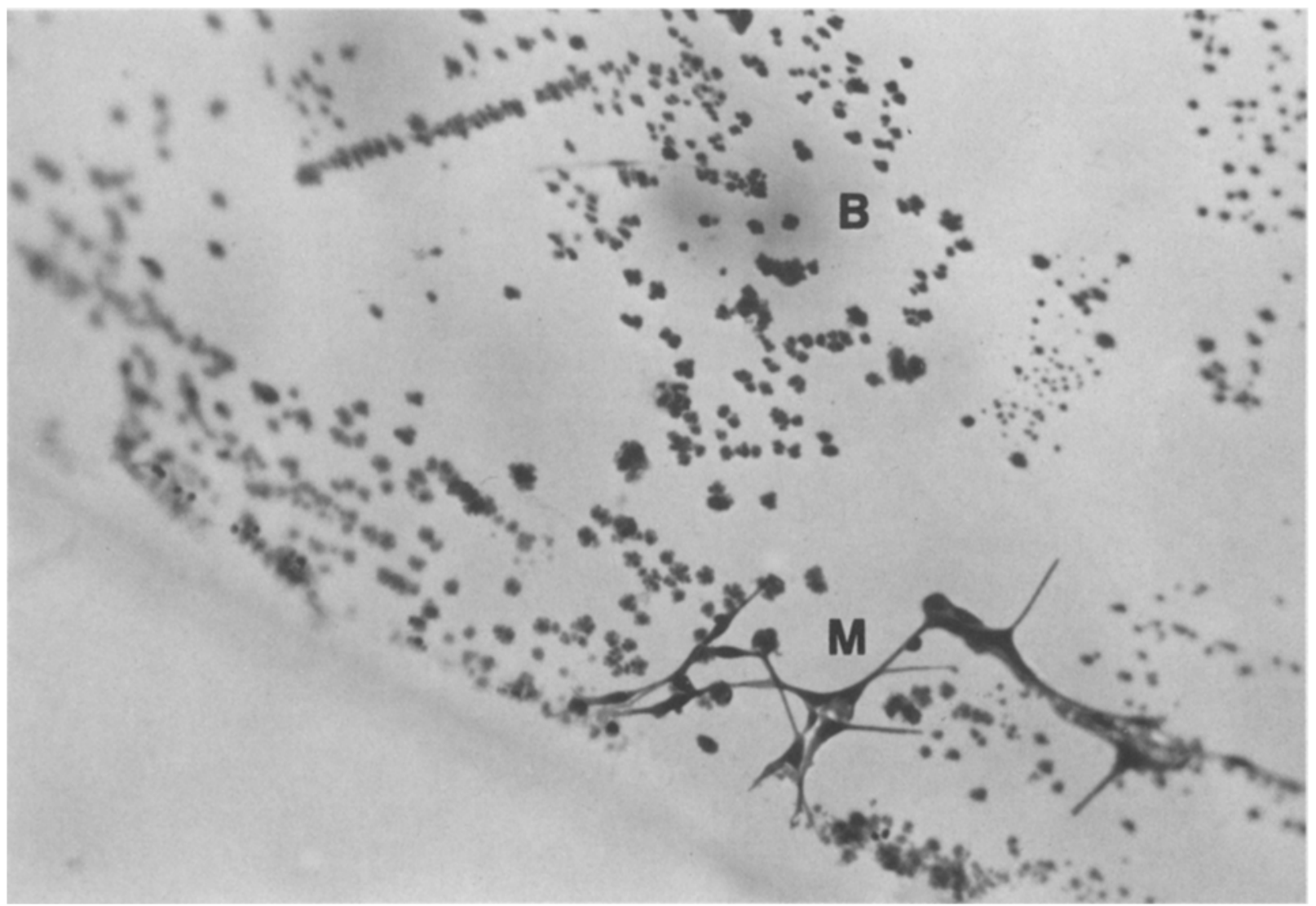

Fig. 6. Second case, a group of 11 melanocytes $(M)$ in an area with partly phagocytized and partly free blood $(B)$ on the continuous capsule of the posterior surface of the optic portion. The edge of the implant is towards down and left. - Lens implant cytology technique, $\mathrm{H}$ and $\mathrm{E}$ stain, photomicrograph $\times 125$ 


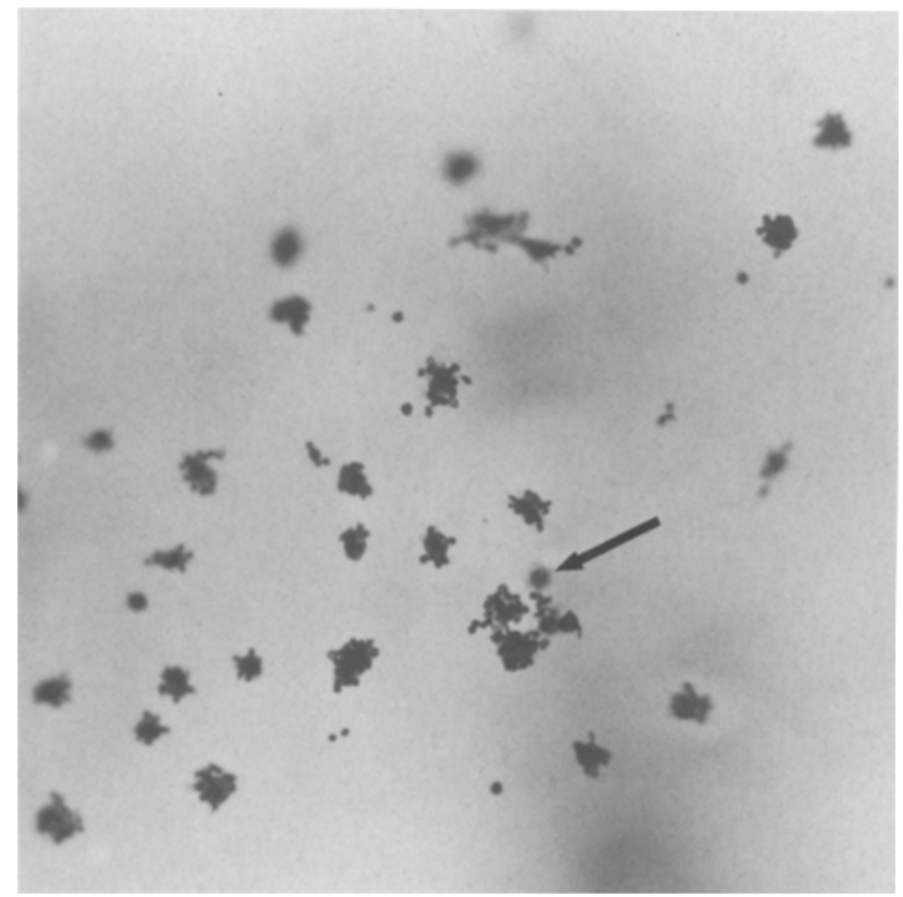

Fig. 7. Second case, about 30 blood-filled macrophages and one small cell without blood (arrow) on the surface of the clear capsule covering the implant. Lens implant cytology technique, $\mathrm{H}$ and $\mathrm{E}$ stain, photomicrograph $\times 125$

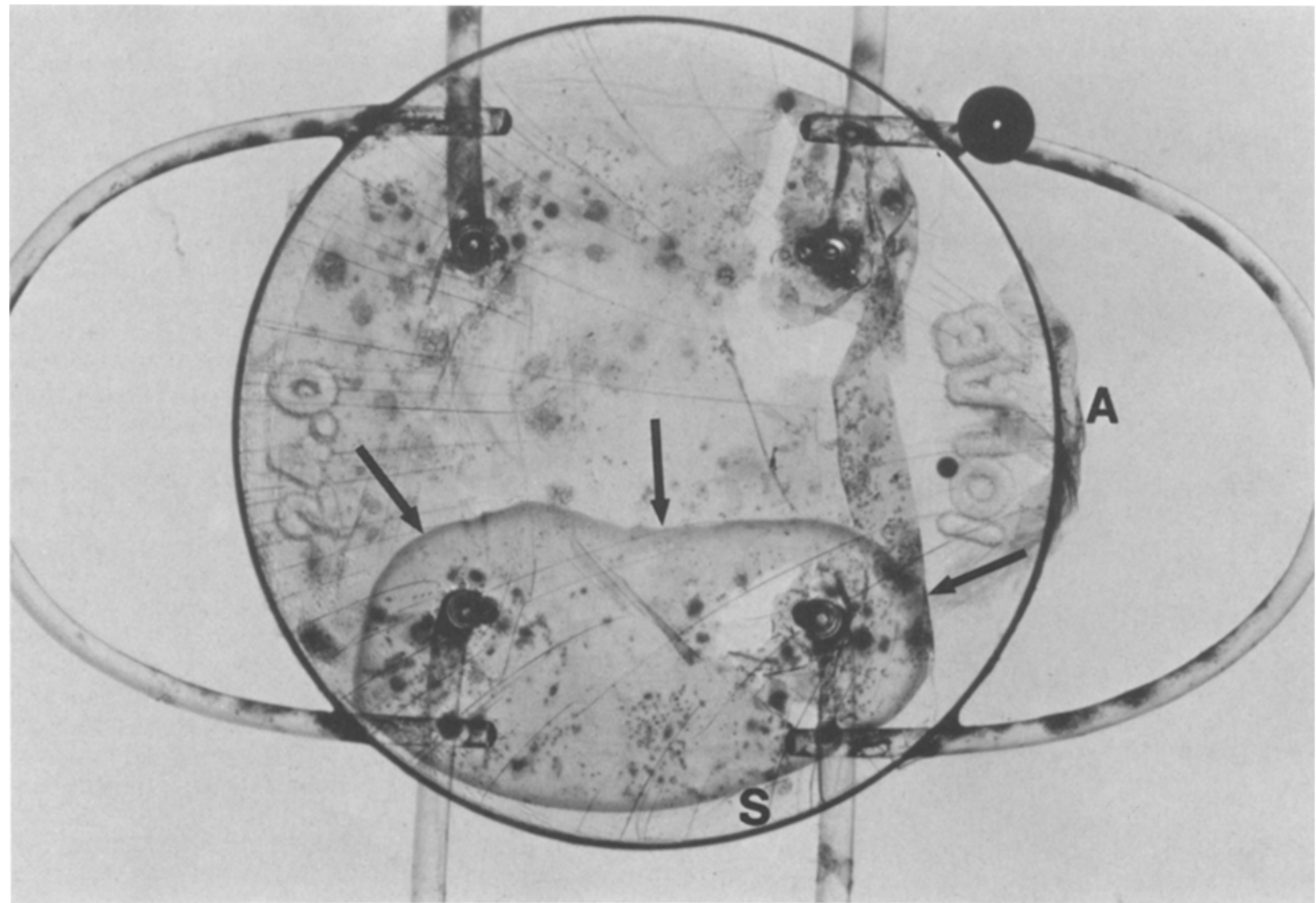

Fig. 8. Third case, low power of implant removed about one year after implantation. Segmental thickening of the posterior capsule is seen below (arrows). Artificial shrinkage of the posterior capsule $(S)$ has exposed the edge of the optics below and on the right. A piece of the torn anterior capsule $(A)$ is piled up on the right. Large giant cells are seen all over the implant. The black spot is caused by an air bubble. - Lens implant cytology technique, $\mathrm{H}$ and $\mathrm{E}$ stain, photomicrograph $\times 20$ 


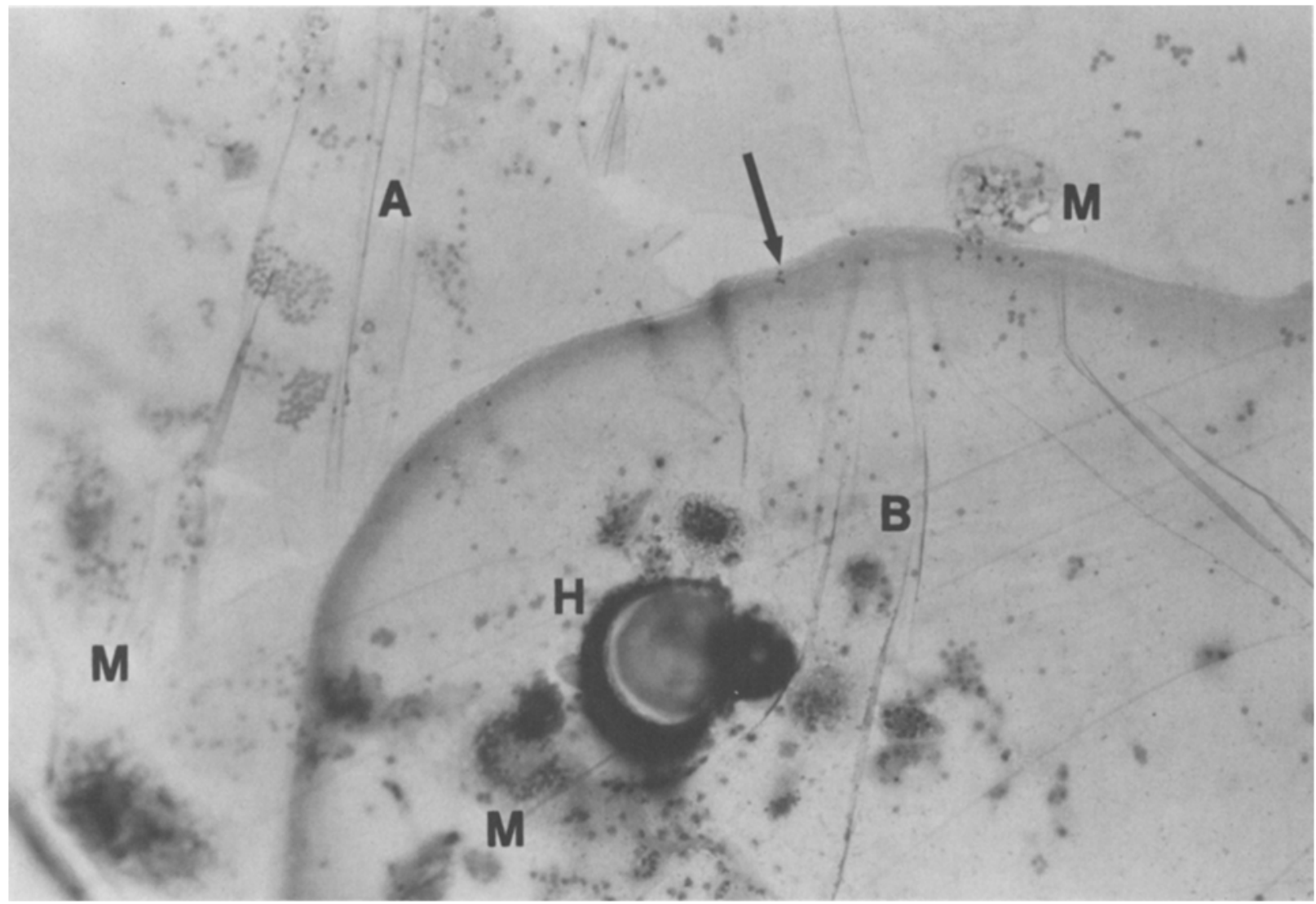

Fig. 9. Third case, higher power showing the border of the thickened portion of the capsule (arrow), large multinucleated giant cells $(M)$, and insertion of one haptic $(H)$. Wrinkles in the casule are more delicate in the thin portion $(A)$ as compared to the thick segment $(B)$. Small macrophages and fibroblast-like cells are seen all over. Lens implant cytology technique, $\mathrm{H}$ and $\mathrm{E}$ stain, photomicrograph $\times 100$

lated on its anterior surface - directly next to the space from which the lens implant had been removed. Iris and ciliary body were involved with some scarring, atrophy, distortion, and diffuse mononuclear infiltration. The condensed anterior portion of the retracted vitreous contained blood with quite a few pigment filled macrophages and occasional PMN's. The retina exhibited advanced atrophy of its inner layers. Loose blood was accumulated on the surface of the atrophic optic nerve head. Diffuse calcification was observed in scleral lamellae all around.

Lens implant cytology studies of the medallion lens removed from this right eye revealed a thin eosinophilic capsule of very regular thickness tightly covering all of its optic and haptic parts (Fig. 4). Fibrous strands containing remnants of zonular fibers were found anchored to the haptic loops (Fig. 4). No foreign body giant cells were seen on the implant, but there were occasional large epithelioid cells with single nuclei of giant size (Fig. 5). In two zones near the border of the posterior surface of the implant, where this had been in contact with the iris stroma next to the pupil, groups of deeply pigmented star-shaped or bipolar cells with very distinct borders and straight processes were seen (Fig. 6). These cells were quite distinctly different from the so-called fibroblast-like cells and macrophages commonly seen on lens implants (Fig. 3). All over the membrane on this implant there were star-shaped macrophages with accumulated whole erythrocytes in and on their protoplasm (Fig. 7). Some of these cells also contained blood remnants and blood pigment. More loose blood rem- nants and whole erythrocytes were seen on the posterior surface of the implant, especially. The star-shaped cells were actively involved in the phagocytosis of blood remnants and whole erythrocytes on the surface of the implant. All the indications are that these cells were mobile and they all had as many erythrocytes in or attached to their protoplasmatic arms as they could handle. It is important to emphasize that there were no signs of fibrosis or a fibrous membrane on or next to the surface of the optical portion of this implant.

Third case: This 73 year-old female had extracapsular cataract surgery with implantation of a crossed iris-clip fourloop intraocular lens in 1981. The eye developed slowly progressive irritation and central vision loss to 20/80. Dr. Raymond A. Rizutti of Brooklyn, N.Y. removed the implant on 11.17.82, fixed it in $10 \%$ buffered Formalin, and sent it for implant cytology study. Most of the membrane on the anterior surface of this lens was torn off and only remnants of it were seen (Fig. 8). However, the membranes on the posterior surface and on all haptics were very well preserved. Numerous large foreign body giant cells were rather evenly distributed all over these membranes (Figs. 810). Most of the giant cells had centrally accumulated nuclei and the nuclear zone was more eosinophilic than the remainder of the protoplasm (Fig. 9). There also were numerous epithelioid cells, some with an unusually clear protoplasm (Fig. 10). Small fibroblast-like cells and active macrophages were distributed evenly in the interspaces (Figs. 9 


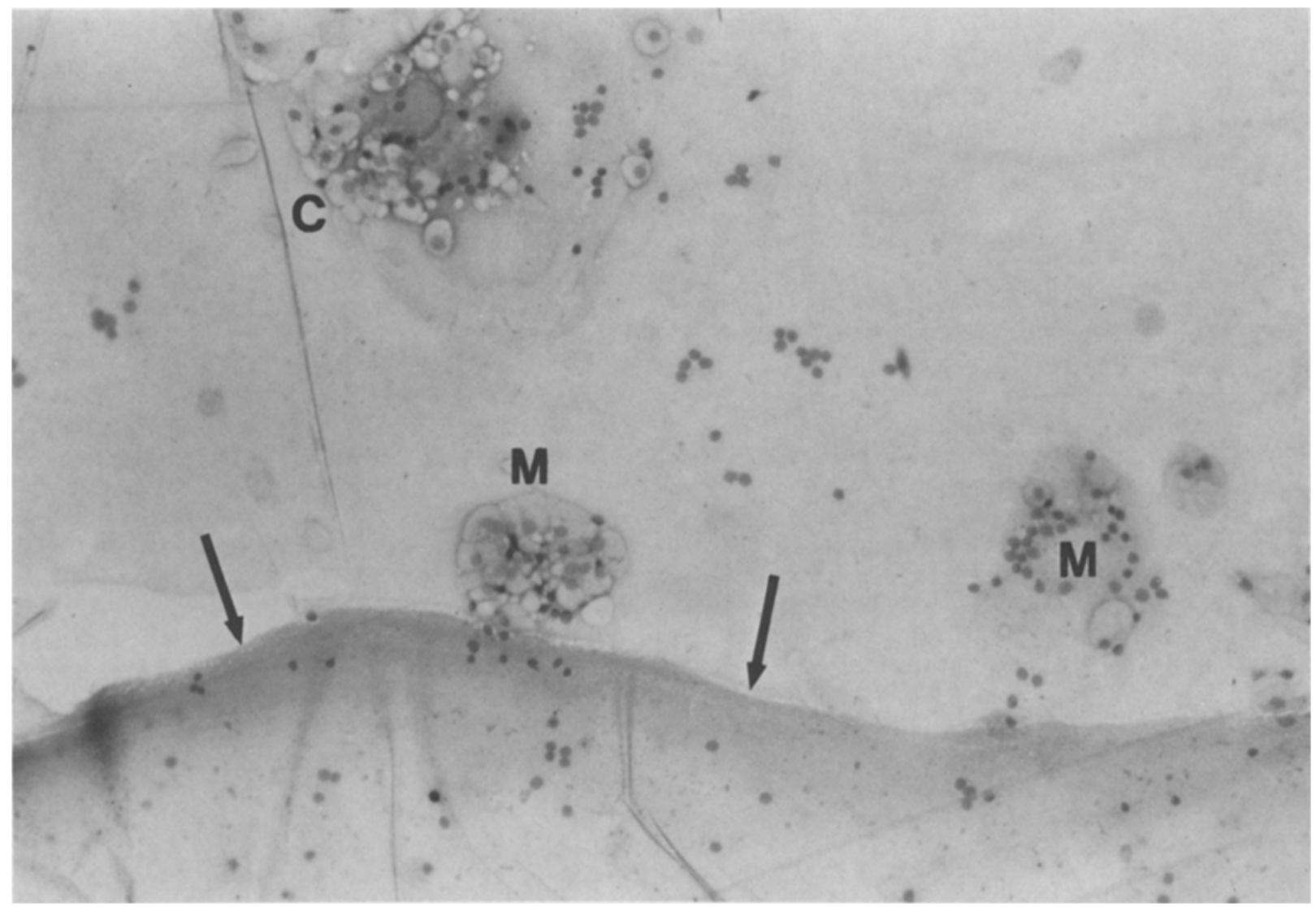

Fig. 10. Third case, high power shows the large multinucleated giant cells $(M)$ near the border of the slightly wrinkled and more eosinophilic segment (arrows). Unusually clear epithelioid cells $(C)$ are seen around one giant cell. Macrophages populate the interspaces. - Lens implant cytology technique, $\mathrm{H}$ and $\mathrm{E}$ stain, photomicrograph $\times 125$

and 10). The film-like capsule on this lens, surprisingly, had a segmental zone of sharply limited thickening and increased eosinophilic staining (Fig. 8). The types and the distribution of cells in the area of this thickened capsule were not different from the remainder of the membrane. The border of the thickening was wall-like and clearly limited the extend of at least one of the large giant cells (Fig. 10). The capsule was not detached in the thickened zone and some wrinkling of the capsule confirmed the first impression that there was more substance to the capsule in the darker zone (Figs. 9 and 10).

\section{Discussion}

The capsular portion probably is the practically most important part of the separating membranes that typically form on the surface of intraocular lens implants. This capsular portion is similar in many ways to the lens capsule of the normal eye that separates the epithelial lens structures from the intraocular fluids. The capsular formation on lens implants becomes firmer and more glass-membrane-like with time and it certainly presented as a tough and firmly adherent structure after 4 years in the first and after 9 years in the second case.

Using a tissue culture model with mouse macrophages on lens implants in the laboratory, it is possible to grow membranes composed of cells and film-like capsules similar to those seen on the implants within a few days [9]. This means that more about the composition of these capsules will probably be known in the near future. The formation of the capsules is associated with the adherence and proliferation of macrophages on the surface of the implants. However, it is not as yet clear, whether or not the capsules actually are a product of the macrophages. While the macrophages (histiocytes, phagocytes) also are the origin of the large giant cells commonly present on lens implants, the indications are that the presence of giant cells is not essential for the formation of the capsules.

The formation of a continuous capsule probably is a very important step in the process of acceptance of an implant in the inner eye. A certain amount of cell life on the surface of the capsule continues, but this no longer directly involves the substance of the implant. The first and second cases of this study show that the capsules on successful implants need little maintenance by cells, once they are formed. The findings in the third case indicate that the capsules do not always develop evenly all over the implants. They can be thicker in some portions than in others. From earlier studies we know that not all membranes on implants have continuous capsules and that contact between implant and formed vitreous, for example, can locally prevent formation of a capsule [8]. With time, the capsules on implants become tougher, more firmly adherent, and less eosinophilic.

A certain number of mobile macrophages usually remain on the surface of the capsules and compared to free-moving macrophages in the eye the macrophages on the implant surface have increased phagocytic capabilities. 
They can phagocytize whole erythrocytes, for example [7]. Erythrocytes in the vitreous have a long life time and are not usually phagocytized, until they break down. On the capsule of the third implant of the present study the hungry macrophages are seen to hold on to as many whole blood cells with their pseudopodia as they possibly can and additional erythrocytes are seen in their protoplasm. It is as if these cells are especially equiped to clean the surfaces of capsules on lens implants.

The second case of the present paper serves well to demonstrate groups of melanocytes on the surface of a continuous capsule. These cells may be found on parts of implants that have direct contact with iris stroma. Melanocytes on implants are distinctly different from macrophages or fibroblast-like cells with pigment in their protoplasm. Melanocytes have non-branching processes and very distinct cell borders. Iris melanocytes have a known tendency to extend onto the corneal surface, when the iris stroma takes direct contact with the cornea and when the corneal endothelium is atrophic [10]. On the posterior corneal surface melanocytes can proliferate and form a dense layer of cells. On lens implants melanocytes haven not as yet been seen to truly proliferate. Melanocytes have been seen on implants only as single cells or in small groups in a few rare case [4].

The fact that strands of fibrous vitreous commonly attach themselves to the haptics and to other parts of implants has recently been reported in detail [8]. These attachments occur in portions that are exposed to the vitreous. Thus, they are most common in posterior chamber implants and in iris supported implants with haptics in back of the iris. The first and second cases of the present paper also show fibrous strands attached to some of the haptics, but these strands do not look like condensed vitreous. A capsule cannot be seen in their region. However, they contain pieces of zonular fibers as the only recognizable part. After intracapsular cataract surgery the zonular fibers remain on the surface of the vitreous and it is not very surprising that they can take part in a fibrosing process involving the haptics and, thus, become attached. At this time it would be an impossible dream to think that all the zonular fibers could be attracted to parts of implants to serve once more for their support, but this possibility certainly has to be kept in mind for the distant future.
Presently, new facts about the glass-membrane-like capsule as well as new attachments and cell types are found on almost every implant that is stained. The epithelioid cells with giant nuclei seen in the second case are a good example for a bizarre cell type that is not understood in its significance at this time. With time, we will learn more about the origin, function, and nature of all structures, cells, and cell remnants on implants, I am sure. The possibility to study these structures and cells has opened a door into a new world. The value of these observations for the eye surgeon is obvious. However, it may well be that the observations on the optically clear lens implants reveal principles that may be valid and important throughout the whole field of Medicine, whereever foreign substance is used to replace normal tissue components.

\section{References}

1. Wolter, J.R. (1982) Lens implant cytology. Ophth. Surg. 13:939-942

2. Wolter, J.R. (1982) Cell life on the surface of lens implants. von Graefes Arch. Ophth. 218:244 249

3. Wolter, J.R. (1982) Foreign body giant cells on intraocular lens implants. von Graefes Arch. Ophth. 219:103-111

4. Wolter, J.R. (1982) Pigment in cellular membranes on intraocular lens implants. Ophth. Surg. 13:726-732

5. Wolter, J.R. (1983) Proliferation of fibroblast-like cells on failing intraocular lenses. Ophth. Surg. 14:57-64

6. Wolter, J.R. (1983) Reactive membrane on a lens implant: three months after implantation. von Graefes Arch. Ophth. in print

7. Wolter, J.R. and Lichter, P.R. (1983) Fibroblast-like cells on intraocular lens implants: phagocytizing erythrocytes. Brit. J. Ophth. submitted

8. Wolter, J.R. (1983) Direct vitreous reaction to intraocular lens implants. von Graefes Arch. Ophth. in print

9. Wolter, J.R., Kunkel, S.L. (1983) Adherence of mouse macrophages to plastic lens implants: resulting in the formation of a cellular membrane. Ophth. Surg. submitted

10. Wolter, J.R. (1981) Replacement of the corneal endothelium by melanocytes. von Graefes Arch. Ophth. 217:247-253

Received January 19, 1983 